\title{
On the Synergy of Modalities and Multimodal Teaching Model of Integrated Business English
}

\author{
WANG Xin \\ Leshan Normal University, Leshan, China
}

\begin{abstract}
This paper firstly reviews the characteristics and current situation of business English teaching, especially pointing out the four main problems in practical teaching. Then it introduces the theory of Multimodal Discourse Analysis and its important influence on modern multimedia foreign language teaching. By analyzing a teaching case of the integrated business English course, the author discusses the synergy of different modalities to achieve the teaching goal in the 10 stages of the actual teaching. Finally, it tries to construct a multimodal teaching model of integrated business English from four aspects: expanding multimodal teaching content, exploring multimodal teaching approach, carrying out multimodal practice activity, and improving multimodal evaluation system.
\end{abstract}

Keywords: Multimodal Discourse Analysis, integrated business English, synergy of modalities, multimodal teaching model

\section{Introduction}

Since 2007, the Ministry of Education officially approved the establishment of Business English, the business English discipline has developed rapidly, and its subject orientation has gradually become clear. The National Criterion of Teaching Quality for BA Program in Business English, which was launched in October 2013, clearly states that the undergraduate major in Business English has interdisciplinary characteristics, and its subject base relies on foreign language and literature, applied economics, business administration, and law (international commercial law). With the emphasis on business language application, business knowledge and practice, and cross-cultural business communication skills, the talent training objectives highlight the three characteristics of internationalization, compound, and application, aiming at cultivating compound and applied talents with English application ability and business practice ability, cross-cultural communication ability, speculative and innovative ability, and independent learning ability who can engage in international business work (Wang \& Ye, 2015). However, according to the author's survey, there are lots of problems in the practical teaching of many domestic college business English majors, and the dual learning of business and language cannot be well balanced. This paper aims to combine business English teaching practice with Multimodal Discourse Analysis theory, taking the integrated business English course as an example and exploring the multimodal teaching model of business English to cultivate students' multimodal business communication competence and improve the teaching effect of business English by analyzing the interaction and synergy of different modalities in communication.

WANG Xin, Master Degree, associate professor, School of Foreign Languages, Leshan Normal University, Leshan, China. 


\section{Characteristics of Business English Teaching and Its Teaching Status}

Ellis \& Johnson (2002) argues that the Business English program has a dual teaching goal of teaching students English and teaching students to use English to engage in international business. Business English teaching reflects the concept of "student-centered" and "capacity-oriented". The teaching goal is to combine international business knowledge and English language knowledge to make students use the correct English for business communication in a cross-cultural context (Chen, 2016).

Through the investigation and communication with business English teachers in the college where she works, the author found that at present, the teaching status of many domestic universities, especially the new business English majors of some local institutions, are not optimistic. Some typical problems are as follows.

\section{Unclear Teaching Goal}

As mentioned above, around the professional positioning and talent training goals, the Business English major has the dual teaching objectives of teaching English and teaching students to use English for international business. However, in the actual teaching, many teachers are not clear about the teaching objectives of the business English course. They think that just directly translating the content of the business texts, focusing on the practice of some words, phrases, and sentence patterns is enough, so that students can master some technical terms. They ignore the business context and the business communication attributes of the language. Such teaching is only a repetitive teaching of English language knowledge, and cannot achieve a comprehensive improvement of business ability and English competence (Zhang \& Li, 2012).

\section{Traditional and Obsolete Teaching Model}

The business English teaching model is developed on the basis of general English teaching theory and ESP teaching theory, and has become a kind of teaching method that highlights a variety of learning-centred or student-centred approaches. This sum of approaches refer to the so-called full English teaching approach, situational teaching approach, question and answer method, task-based teaching approach, communicative language teaching etc. All these teaching approaches try to reflect the differences of teaching mode between business English and ordinary English in cultivation objectives, curriculum, teaching materials construction, teaching methods and evaluation mechanism and even the differences with the ESP teaching mode. These unique features are the characteristics of the business English teaching mode (Zhu, 2010). However, many business English classroom teachings are still teacher-centered, and most teachers just use the oral and written language to transfer knowledge, mainly adopting the "Grammar-translation Method". The explanation of practical knowledge lacks the design of business context and the arrangement of practical activities. The Humanities and Social Sciences Project of the Ministry of Education, "Research on the Status, Problems and Countermeasures of Business English Professionals’ Demand and Cultivation”, conducted a questionnaire survey on 10 colleges and universities that applied for business English earlier, and investigated 115 front-line teachers and collected 96 valid questionnaires, of which "the main problems existing in the development of business English majors in China", the teachers selected the most, including that the teaching model is homogenous and lacks of diversities, the teaching methods are outdated, basically following the traditional English teaching route (Bian, 2018).

\section{Weak Practical Teaching}

Business English is a very practical undergraduate major. Practice teaching is precisely the key link 
integrating language and business, connecting knowledge and skills. Li Gang (2014) found through investigation that the main problems in the practice teaching of business English major include: unclear understanding of practice teaching objectives, unsystematic teaching content, unclear evaluation criteria of teaching effects, and the substandard practice bases in both quantity and quality. Through the investigation of the current situation of business English major teaching in Leshan Normal University and other universities in China, the author also found that due to the inadequate school hardware, the imperfect curriculum system and the delayed construction of the practice internship base, the combination of book knowledge and social practice skills of business English major teaching lacks of effective classroom and after-school, on-campus and off-campus methods, leading to the failure of students to apply professional knowledge to social practice, which cannot meet the requirements of social employers.

\section{Uni-dimensional Evaluation System}

The National Criterion of Teaching Quality for BA Program in Business English stipulates: "The evaluation of undergraduate teaching in business English should focus on the combination of formativeness and finality, and highlight the quality, knowledge and ability of students” (Wang et al., 2015). However, the curriculum evaluation in many universities is still based on the final evaluation of the final exam paper. The formative evaluation is mainly based on the attendance rate and the written assignments after class. Basically no innovative business practice activities and a multi-dimensional evaluation system based on online learning and training platforms are introduced. In terms of validity or reliability, this traditionally uni-dimensional evaluation cannot objectively and scientifically reflect the true level of students, nor can it provide effective guidance for the improvement of classroom teaching.

\section{Multimodal Discourse Analysis Theory}

The theory of Multimodal Discourse Analysis originated in the 1990s and is based on Halliday's Systemic Functional Linguistics. The theory of Multimodal Discourse Analysis was first proposed by O’Toole, Kress, and Van Leeuwenn. Its theoretical starting point is that language is a social symbol. It extends the function of language as a social symbol to other symbols besides language, and regards various symbols including language as independent and interactive symbol resources, emphasizing the role of visual, auditory, and behavioral symbols such as image, color, sound and motion in discourse (Zhang, 2010). With the development of multimedia information technology and the advent of the digital network era, only language is difficult to meet the needs of modern communication. More and more non-verbal symbols are involved in meaning construction and discourse communication. In this context, English classroom discourse is taking on typical multimodal features, that is, students have multiple channels of perception, such as vision, hearing, smell, touch, etc. The material media and technical media required for teacher-student communication are diversified, and the use of these channels and media in the classroom produces a variety of symbolic resources, such as language, sound, motion, facial expressions, images, music, animation, color, etc. (Wang, 2010). Many scholars in China have proved that Multimodal Discourse Analysis provides theoretical basis and guiding standards for multimodal English teaching, which offers a new dimension and perspective for language teaching design research (Hu, 2007; Zhu, 2009; Zhang, 2010; Zeng, 2014).

However, at present, domestic researches on the Multimodal Discourse Analysis of business English classroom teaching are still rare. Based on the discipline characteristics of business English teaching, the author 
attempts to place the business English teaching in the framework of Multimodal Discourse Analysis and the multimodal context, which is not only an important way to solve the problems in teaching practice and improve the effectiveness of teaching, but also an inevitable trend to adapt to the development of the times and promote the reform of business English teaching.

\section{Multimodalization of Business English Teaching Model}

Studies have shown that teaching discourse is no longer a "language alone" situation; classroom teaching is completed by a variety of modalities, including space, gestures, gaze, body, movement, sound, tone, music, three-dimensional objects, spoken language, written language, graphics, tables, drawings, animations, etc. (Jewitt, 2009). The content of business English courses is interdisciplinary and practical, and involves various aspects of business activities, such as international marketing, international trade, market competition, corporate culture, globalization, e-commerce, etc., so it is particularly important in the choice of modality (Chen, 2016).

The author works in the Business English Department of Leshan Normal University and takes the comprehensive business English course as an example. The selected textbook of this course is Business English: An Integrated Course (Volume 3) published by Shanghai Foreign Language Education Press and edited by Wang Lifei. The materials are novel and rich in content, including all aspects of China and global business activities, such as business travel, eco-tourism industry, workplace pressure, social health insurance, Western welfare system, market capital operation, unemployment, entertainment industry, art commercialization, public relations, etc. Due to space limitations, the author selects the business theme "social welfare" of the third unit as a specific example and takes the video of the open course of a young teacher in the business English department as the analysis object. Under the guidance of the Multimodal Discourse Analysis theory, the author focuses on the analysis of the teacher how to select, invoke, and coordinate different modalities and other teaching resources in multimodal classroom teaching, which jointly construct the meaning of business English classroom discourse, help students understand, internalize and master business English knowledge from different angles, and finally form the effective multimodal teaching model of comprehensive business English course.

\section{The Cooperation and Synergy of Different Modalities in Integrated Business English Classroom Teaching}

From the perspective of modality, the classroom teaching of this integrated business English course involves the cooperation and synergy of various modalities. Different modalities play different roles in different stages of classroom teaching. At each stage, the teacher selects and invokes the required modalities according to teaching objectives. Then the author will explore how the different modalities synergistically realize the meaning of classroom teaching discourse in the 10 stages of the lesson.

(1) The main modality of the class ceremony is spoken language: The task of this stage can be completed through the greetings without using other modality; (2) Introducing the teaching objectives, teaching content, and teaching tasks of the course: The main modality is spoken language, images, and text. The latter two are presented through PPT, which has the effect of quickly attracting attention and deepening the impression; (3) Lead-in stage: Firstly, the background vocabulary and phrases related to "social welfare" are derived in the form of mind map, such as salary, minimum wage, subsidy, pension, health care, job security, medicare, 
benefactor, beneficiary, social insurance, welfare state, then pair up students to discuss the welfare benefits you want to have from your future jobs. The main modalities are spoken English, text and graphics. The text mainly assists in providing business background information, enables students to understand relevant terms, and presents key information as the questioner, and dialogue is used to stimulate students' interest in listening and speaking; the mind map is mainly to strengthen the textual modality, stimulate students' brainstorming, and promote the flow of thoughts; (4) Pointing out the theme: Introduce the main features and differences of social welfare systems in Europe, the United States, and China by playing a multimedia video. The main modalities are video, sound, music, text, and spoken English. Through the video, China's and Western social welfare system will be displayed to familiarize students with their characteristics and guide them to preliminarily point out their respective advantages and disadvantages; (5) Developing the theme: The teacher summarizes the main differences between China's and Western welfare systems and briefly analyzes their causes, and then guides students to think about the following question and make a choice: Which job will you choose on graduation? A fortune 500 corporation or a civil servant, and why? The main modalities are text, spoken English, and images. By comparing the advantages and disadvantages of China's and Western welfare systems, students will further recognize the characteristics of different countries' institutions and social forms, as well as improve their oral skills through discussion; (6) Text learning: Read text I "Job Insecurity and the Welfare State in a Globalized World”. The main modalities are spoken language, text, and images. The teacher has made the relevant reading materials into vivid PPT, and teaches the skills of locating topic sentences and scanning specific information in the reading process through case teaching; (7) Role-play task: The main modalities are spoken English, text, and sound. The teacher provides the simulate business situation and background information, and pairs up students to compose a five-minute dialogue about the job interview. Two students are required to play the roles of interviewee and interviewer. The former asks about and negotiates the salary and other welfare of the position he applies for, and the latter explains what can be offered according to the applicant's qualifications. Three pairs can be selected to the platform to display their dialogue with the spatial position adjusted to a simulate situation; (8) Summary: The main modalities are spoken and written English. The teacher makes a brief review of the business knowledge and language skills of this lesson; (9) After-class assignments: The main modalities are spoken English, image, and text. The teacher first displays the structure of the survey report and its commonly-used phrases through the PPT, and then assigns a survey task: write a short summary of the similarities and the differences between the NHS in Britain and the Medicare in America; (10) The end: The main modality is spoken English. The after-text written exercises are assigned and the lesson comes to end.

In the classroom discourse of this open class, various modalities work together, especially the spoken modality of the teacher-student communication and the text, image, and video modalities represented by the PPT. Although spoken language is the main modality of classroom teaching, it cannot effectively complete the teaching task alone, which needs to be completed by other modalities, especially those carried by PPT. Thus, a synergistic relationship exists between PPT and spoken language (Zhang \& Li, 2012). In addition, there are other modalities like mind map, reading materials, pictures, teachers' rich body language, such as gestures, facial expressions, tones, and body movements, spatial layout in the classroom, and free discussion, dialogue, music, and audio, etc. This combination of visual, auditory, and tactile modalities can stimulate student's brain, which is much stronger than single text or single modality, which is more conducive to the teaching of knowledge and skill. 


\section{Multimodal Teaching Model of Integrated Business English}

The above example of integrated business English teaching show that teachers can fully use multimodal discourse in classroom teaching to stimulate students' various sensory operations and improve teaching efficiency and effects. How to further enhance the modal diversity in the classroom teaching process to the multimodal teaching model of integrated business English, which the author believes, can be further explored from the following four aspects based on the study of former scholars (Yi \& Duan, 2013).

Expanding multimodal teaching content around textbooks. At present, in addition to several major foreign language education presses which publish integrated business English textbooks in China, such as New Horizon Business English: A Comprehensive Course, published by Foreign Language Teaching and Research Press, Market Leader Elementary Business English Course Book published by Higher Education Press, Business English: An Integrated Course published by Shanghai Foreign Language Education Press, and Success with BEC published by Economic Science Press, etc., many university presses have also published integrated business English course textbooks. Although the textbooks of integrated business English have increased in number and type, the textbooks whose quality is truly satisfactory to users are still relatively scarce. Bian Lizhi (2018) believes that a good business English textbook should not only help to achieve the teaching objectives of the course, but also meet the needs of learners and society for business English knowledge and skills, while also stimulating students' interest and autonomy in learning. To build a multimodal teaching model of integrated business English, it is very necessary to choose the multimodal textbooks with the combination of graphics, text, sound, image, and even online media, which are fully integrated with artistry, interaction, and fun. However, only textbooks are not enough for multimodal teaching content. No matter which kind of teaching materials are used, business English teachers need to make full use of the rich Internet and library multimodal teaching resources to collect and select teaching materials of international business activities as the supplement for textbooks, including text, pictures, graphics, video, audio, etc., such as the annual reports of multinational corporation, data reports, meeting minutes, business advertisements, charts, etc.

Exploring multimodal teaching approach according to content. Business English teaching model is a sum of teaching approaches that emphasize learning-centeredness or student-centeredness (Zhu, 2010), such as task-based teaching approach, content teaching approach, cooperative learning approach, case teaching method, situational teaching approach, communicative language teaching, narrative teaching approach, etc. In the new media era, these traditional business English teaching approaches must be combined with modern multimedia means to gradually realize the multimodality of the course. Teachers need to choose and explore appropriate teaching approaches according to different text themes and teaching content, and at the same time integrate multimodal stereoscopic means such as sound, image, video, audio, animation, etc., to create close-to-real business situations for students, thus effectively improve students' business English communication skills.

Carrying out creative multimodal practice activities. Business English as applied English in the international business environment attaches importance to practice. In the teaching process of integrated business English course, the designed classroom communication activities can guide students to apply both English and business knowledge to practice activities, so that students can truly master the language and business knowledge they have learned. Compared with the traditional teacher-dominant or rigid class dialogue, students are more enthusiastic about commentary, discussion, debate, speech, simulation performances, and other lively and creative language communication activities (Yi \& Duan, 2013). On the one hand, in the 
traditional classroom teaching, teachers can make full use of PPT multimodal resources and flexible classroom space settings to design classroom practice activities according to the topic of the text, such as business situational dialogue, business briefing, business negotiation, business speech, business etiquette display. On the other hand, some courses can be arranged in the multimodal training room that simulates the real scene, which is convenient for teachers to invoke more online and offline multimodal resources to carry out business practice activities, such as analog online e-commerce, business correspondence writing, business interpreting contest, offline trade negotiations, etc.

Relying on the data to improve the multimodal evaluation system. Based on the previous multimodal teaching content, teaching approaches, and practice activities, the evaluation means of the integrated business English course should not be the final evaluation in terms of final exam or the formative evaluation in terms of the student attendance and written homework. It should be accordingly characterized by multimodality. The evaluation system should include the final results at the end of the course, as well as the comprehensive evaluation of the teaching effects, the changes in student level, the participation of students in the practice activities, and the students' online learning time on the business platform during the course. Therefore, the evaluation system of the integrated business English must be procedural, individualized, and emphasizes students' language proficiency (Zhang \& Li, 2012). This requires teachers to design a scientific and operational multimodal curriculum evaluation system in advance, formulate specific evaluation scales, and integrate the data of student-student mutual evaluation, software evaluation, and teacher's evaluation to form the final course score according to a certain proportion.

\section{Conclusion}

With the high integration and deep penetration of modern information technology and new media in the field of foreign language teaching, and The National Criterion of Teaching Quality for BA Program in Business English has put forward higher requirements for the orientation and training objectives of business English, the traditional business English teaching will inevitably face great changes. The integrated business English teaching under the guidance of Multimodal Discourse Analysis requires teachers to fully consider the specific teaching scenarios and teaching objectives at each stage, select the appropriate teaching methods and modality combinations, and pay attention to the synergy of different modalities, aiming to make students' various senses participate in the study and experience the real business context. By expanding the multimodal teaching content, exploring multimodal teaching approaches, carrying out multimodal practice activities, and improving multimodal evaluation system, teachers can further construct a multimodal teaching model for integrated business English, which is in line with the teaching requirements of business English in the new era and will promote the development of business communication practice ability of business English majors.

\section{References}

Bian, L. Z. (2018). Ten years' development of Business English major in China: Achievements, problems and solutions. Technology Enhanced Foreign Language Education, (1), 63-69.

Chen, X. L. (2016). On the synergy of different modalities in Business English classroom discourse. Journal of Minjiang University, (6), 91-95.

Ellis, M., \& Johnson, O. (2002). Teaching Business English. Shanghai: Shanghai Foreign Language Education Press.

Hu, Z. L. (2007). Multimodalization in social semiotics. Language Teaching and Linguistic Studies, (1), 1-10.

Jewitt, C. (2009). The Routledge handbook of multimodal analysis. London: Routledge. 
Li, G. (2014). Construction of the practice teaching system of Business English major-A case study of Business English major at CWNU. Technology Enhanced Foreign Language Education, (11), 76-80.

Varner, I. I. (2000). The theoretical foundation for intercultural business communication: A conceptual model. Journal of Business Communication, 37(1), 39-57.

Wang, L. F. (2015). Key issues in Business English program development under the guidance of the National Criterion of Teaching Quality for BA Program in Business English. Foreign Language Education in China (Quarterly), (2), 3-8.

Wang, L. F., Ye, X. G., Yan, M., Peng, Q. L., Xu, D. J. (2015). Interpretation of the National Criterion of Teaching Quality for BA Program in Business English. Foreign Language Teaching and Research, (3), 297-302.

Wang, Y. H. (2010). Image-text relation in multimodal discourse. Foreign Language and Literature, (5), 73-75.

Weng, F. X. (2014). On the dual-track development mode of Business English. Foreign Language World, (2), 10-17.

Yi, X. Q., \& Duan G. X. (2013). An analysis of the construction of multimodal Business English teaching model. China Electric Power Education, (35), 227-228.

Zeng, L. (2014). The study of the multimodal discourse in College English Teaching. Journal of University of Science and Technology Beijing, (10), 9-15.

Zhang, D. L. (2010). Preliminary investigation into the concept of design and the selection of modalities in multimodal foreign language teaching. Foreign Languages in China, (5), 48-53.

Zhang, D. L., \& Li, Y. X. (2012). The study on the synergy of modalities of multimodal discourse. Foreign Languages and Their Teaching, (1), 39-43.

Zhu, W. Z. (2010). Business English teaching mode: Its theoretical evolution, features and performance. Journal of Guangdong University of Foreign Studies, (7), 22-27.

Zhu, Y. S. (2009). Theory and methodology of Multimodal Discourse Analysis. Foreign Language Research, (5), 82-86. 